\title{
The Social Support and Assertive Behavior of Students
}

Received March 9, 2020 | Accepted June 26, 2020

\author{
Reza Fahmi* \\ rezafahmi@uinib.ac.id
}

\author{
Prima Aswirna \\ primaaswirna@uinib.ac.id
}

\author{
Universitas Islam Negeri Imam Bonjol Padang
}

\begin{abstract}
Humans are social creatures who need mutual support from one another. So social support contributes to their assertive behavior in social life. Furthermore, this study wants to examine the close relationship between social support and assertive behavior among students The purpose of this study is to explain the categories of social support, certain behavior categories, and the relationship between social support and assertive behavior of students majoring in Islamic Counseling Guidance Imam Bonjol Padang. The research method used is a quantitative research method with correlation techniques that are processed with the SPSS program version 16.0 for windows. The population in this study was 334 students majoring in Islamic Counseling Guidance for Imam Bonjol Padang, with 182 students as the research sample. The sample was taken using proportionate stratified random sampling. Data collection techniques used in this study are psychological scales, which are guided by the Likert model scale. The data analysis technique used is the Pearson correlation. The results showed that $64.3 \%$ of students had high social support, and $73.1 \%$ of students showed low assertive behavior. The results showed relations between social support and assertive behavior.
\end{abstract}

Keywords: Social Support, Assertive Behavior, Students.

\section{INTRODUCTION}

Students are always expected to be able to act as agents of change who are capable of bringing about change in society. As a student, a person will be required to be more independent, more initiative, more mature, and more mature in thinking and behaving. Students are not only needed to have academic abilities, but they are also required to have social skills and have an interest in the discussion so that he can convey what he thinks (Jan Sheinker, 1988). However, in daily life, there are still many students who choose to remain silent, lazy to ask questions, do not express their thoughts, feelings, needs, or desires to others. And not dare to express disapproval, rejection, and criticism of others. This will cause students to be passive, introverted, have feelings of fear, not feel satisfied, less able to express their desires and emotions, so they lack social support, input from others, and make students not get what they want.

Assertiveness is the ability of an individual to express his/her opinion in an honest and open manner, while expressing his/her emotions, thoughts, and the right of the other person (Lambertz \& Blight, 2016). Assertive persons who are able to say clearly what they want to say and who have empathy ability, respect others and who can say no (Uzuntarla et al., 2016; Eliusuk, Gunes, Arslan; 2014). Hojjat et al. found that assertiveness training increased the assertiveness, happiness level, and academic success of students (Hojjat, 2016). It can be considered that assertiveness leads to an increase in communication skills because of the ability to increase interpersonal interaction, to 
express feelings and feelings comfortably, and because people can understand each other better.

According to the fact in the Faculty of Da'wah and Communication Studies. Based on observations made by researchers, it was seen in the sixth semester students of the Da'wah Management Department with a total of 33 students, when their active discussion was only nine people. Sixth-semester students of the Islamic Broadcasting Communication Department with 25 students, who were active during the debate were seven people. Fourth-semester students of the Islamic Broadcasting Communication Department with 37 students, only 5 were active. Sixth-semester students of the Department of Islamic Community Development with 28 students, only 6 are active. While the fourth-semester students of the Islamic Counseling Guidance Department with 39 students, only 4 were active. So, based on these observations, the researchers saw that of the four majors in the Faculty of Da'wah and Communication Studies, it turned out that the Islamic Counseling Guidance Department students were the least active during the discussion because of one indicator of assertive behavior is participating in discussions.

In the context of learning in higher education, students should be required to be more active in elaborating various learning materials. So that various sources of learning materials are an important part of learning in class. Given the limited learning material delivered by lecturers in lectures. So they need to look for material on the internet or journals and books and so on. In learning in the classroom students generally feel awkward to argue or give their opinion as an active attitude in class. This active attitude provides evidence that they are following the learning process that is being carried out. Not only that, but it shows that they are assertive in contributing to the development of knowledge they learn before they enter the classroom.

Assertiveness is actually thought to be not only the things that are done immediately in the learning that they run. But it is part of internalizing the learning process at home. This means that social support in the family will contribute greatly to the formation of their assertiveness on campus. Where the role of father, mother, brother or sister in supporting the formation of courage to argue or argue is assumed to contribute greatly to fostering assertiveness among students on campus.

Furthermore, to support the data above, researchers spread 30 questionnaires related to assertive behavior to students majoring in Islamic Counseling Guidance. It was found that five items indicate that students majoring in Islamic Counseling Guidance show non-assertive behavior. The five questions are students who meet the invitation of a friend even though he does not like it, for fear that his friend will get angry as many as 21 people (70\%), do not tell his friend when he is sad as many as 20 people $(66.67 \%)$, do not always ask questions in the discussion as many as 18 people $(60.00 \%)$, did not congratulate friends who received high scores of 17 people (56.67\%), and students who chose to remain silent and complete their assignments without the help of others as many as 16 people $(53.3 \%)$.

Students, as social beings, will always be in contact with others. Students need to behave assertively in carrying out their learning activities. Assertive behavior is significant for students for several reasons as follows: first, assertive behavior will make it easier for students to socialize and establish relationships with the environment effectively. Secondly, with the ability to express what they feel and want directly, and frankly, students can avoid the emergence of tension and discomfort due to holding and storing something they want to say. Third, by having an assertive attitude, students can 2 
easily find solutions and solve various difficulties or problems they face more effectively. Fourth, assertiveness will help students to improve their cognitive abilities, broaden their insights about the environment, and not quickly stop at something they don't know (Hasanah, Supriyono, Herani \& Lestari 2012).

Behaviors not innate or not assertive nature of one's personality, but the patterns are studied as a reaction to social situations in life. If the individual has assertive behavior, then he will feel his needs fully, not feel afraid, other people will have a positive reaction so that he will have a good relationship with others. Conversely, if an individual cannot implement assertiveness in his social life, it can lead to support that is unhealthy, not harmonious, lack of kinship, often angry, and then will spend time and energy because he hopes they have said or done something that can cause others aware of their existence (Adams \& Lenz, 1995). Assertive behavior is necessary to reduce stress, frustration, or conflict experienced so that it does not escape to negative things. Therefore individuals need other individuals who can provide social support to them.

Further more, Rook said that social support is one function of social ties, and these social ties illustrate the general level of quality of interpersonal relationships. Ties and friendships with others are considered aspects that provide emotional satisfaction in an individual's life. When the environment supports someone, everything will feel more comfortable. Social support shows interpersonal relationships that protect individuals against the negative consequences of stress. Social assistance received can make individuals feel calm, cared for, loved, arises self-confidence, and competence (Smet, 1994). With this phenomenon, the researcher is interested in examining the Relationship between Social Support and Assertive Behavior of students at UIN Imam Bonjol Padang Islamic Counseling Guidance Department. The students. So through this research can be obtained a picture of social support, assertive behavior, and the relationship between social support and the confident demeanor of students.

Our research provides evidence that internalization of social support in families that shape student assertiveness does not necessarily correlate with the social support they receive. This means that social support and assertive behavior only correlate in the low category. Where there are still various other variables that might influence social support which correlates with student assertive behavior. Where this happens if various other variables also support, such as; learning nuance, teaching methods carried out by lecturers, lecturer personalities, peer support and other variables that can also contribute to the correlation between assertive behavior in relation to social support. In another hand, we suggest factors that influence assertive behavior, namely internal factors consisting of age, sex, self-esteem (self-esteem) and external factors including of parenting age, culture, and the environment ( social). Then, In plain language, our study denies that social support is the main determinant of the formation of assertive behavior among students.

\section{METHODS}

The population in this study were students of the Department of Islamic Counseling Guidance UIN Imam Bonjol Padang from 2016 to 2018 as many as 334 people. The data collection method in this research is to use a psychological scale. The scale used in this study is of two kinds, namely the range of social support and the range of assertive behavior. The range of social support in this study was measured through an adaptation scale from Herdiati (2014) using a theory of forms of social 
support according to House, namely: emotional support, appreciation support, instrumental support, and educational support. The scale of assertive behavior is measured through the adaptation scale of Fransiska (2007) by using the characteristics of assertive behavior according to Adams \& Lenz namely: getting along honestly and directly, being able to express their feelings, needs and ideas, being able to act in their interests and take initiatives to meet their needs, ready to ask for information and help from others when they need it, are willing to find satisfactory solutions when in conflict with others, and prepared to defend their rights without violating the rights and needs of others. The data analysis method used was the Pearson correlation statistical technique. The process of data analysis in this study using the program SPSS version 16.0 for Windows.

\section{RESULTS}

The research was conducted to determine the relationship of social support with the assertive behavior of students majoring in Islamic Counseling Guidance at UIN Imam Bonjol Padang. The researchers collected data using a psychological scale. To obtain a more detailed picture of the relationship of social support with assertive behavior, the researchers describe the results of the study as follows:

Table 1 Variable Data Distribution

\begin{tabular}{lrr}
\hline & Social Support & Assertive Behavior \\
\hline The mean & 55.52 & 110.98 \\
Median & 56.00 & 111.00 \\
Minimum & 37 & 90 \\
Maximum & 70 & 146 \\
\hline Source: Research Result Data & &
\end{tabular}

Based on the table 1 above, there are results for social support variables having a mean value of 55, 52, a median of 56, 0 , a minimum amount of 37 , and a maximum value of 70. As for the variable assertive behavior has a mean value of 110.98 , the median of $111,00,9$ minimum value of 0 , and a value maximum amounted to 146. So the description data obtained from the results of the analyst is SPSS version 16.0 for windows, which is used to determine the range values in each variable categorization.

Table 2 Social Support Categorization

\begin{tabular}{cccc}
\hline Categorization & Range & Amount & Percentage \\
\hline Low & $37-53$ & 65 & 35.7 \\
High & $54-70$ & 117 & 64.3 \\
\hline Sum & & 182 & $100 \%$ \\
\hline
\end{tabular}

Source: Research Result Data

Based on the table 2 SPSS analysis version 16.0 for windows found that of 182 students studied, 65 students or $35.7 \%$ had low levels of social support, 117 students, or $64.3 \%$ had high levels of social support. Based on the magnitude of the percentage of social support students majoring in Islamic Counseling Guidance, UIN Imam Bonjol Padang is categorized high. This means that these students get attention, help, and support from others, both family, friends, or the environment. When a problem occurs, they will tell it others, and that person will provide help to him. With this social support, someone will feel that he is cared for and loved. 
Table 3 Assertive Behavioral Categorization

\begin{tabular}{cccc}
\hline Categorization & Range & Amount & Percentage \\
\hline Low & $90-118$ & 133 & 73.1 \\
High & $119-146$ & 49 & 26.9 \\
\hline Sum & & 182 & $100 \%$ \\
\hline
\end{tabular}

Source: Research Result Data

Based on the table 3 analysis of SPSS version 16.0 for windows, found that of the 182 students studied, 133 students or $73.1 \%$ had a low level of assertive behavior, and 49 students or $26.6 \%$ had high levels of assertive behavior. Based on the percentage of assertive behavior of students majoring in Islamic Counseling Guidance, UIN Imam Bonjol Padang is categorized low. This means that students who have little assertive behavior, then students are unable to express what is felt and thought directly, firmly and honestly, can not ask for help from others, and do not dare to reject the wishes of others, even if it is not following it.

Data normality test is an essential requirement in the analysis of parametric data such as correlations because the data to be analyzed parametrically must be normally distributed. This normality test aims to determine whether the population data is normally distributed or not. Normal data distribution states that the research subjects are classified as representative or can represent the existing population; conversely, if the delivery is not standard, then it can be concluded that the issue is not elected or does not represent the current population. The normality test in this study uses the Kolmogorov Smirnov One Sample test. The data are declared healthy if the significance is more significant than 0.05 (Priyatno, 2014: 69).

Based on data management using the SPSS program version 16.0 for windows, the normality test results are obtained as follows:

Table 4 Normality Test for Social Support Scales and Assertive Behavior Scale

\begin{tabular}{lcc}
\hline \multicolumn{1}{c}{ Variable } & Kolmogorov-Smirnov Z & Asymp sig \\
\hline Social Support & .951 & .326 \\
Assertive Behavior & .994 & .277 \\
\hline Source: SPSS Data 16.0 for windows & &
\end{tabular}

To find out whether the data is normally distributed or not, we can find out from the Kolmogorov Smirnov One Sample test table above. The test criteria are if the significance value $>0.05$, then the data is usually distributed. From the chart above, we can know that the significance value (Asymptotic Significance 2-tailed) for social support is 0,326 , and assertive behavior is 0,227 . The significance of the two variables is more significant than 0.05 , then the distribution is normal. So it can be concluded that the scale of social support is usually distributed, and the range of assertive behavior is also normally distributed.

Linearity test is a test to the terms do if it will perform correlation analysis or linear regression. The linearity test aims to determine whether the two research variables have a significant detector relationship or not. Both variables are said to be linear if they have a significance level of less than 0.05 (P <0.05) (Priyatno, 2014: 79).

Based on data management using the SPSS program version 16.0 for windows, the linearity test results are obtained as follows: 
Table 5 Test Linearity Scale of Social Support and Scale Assertive Behavior ANOVA

\begin{tabular}{cccc}
\hline & R Squared & F & Sig. \\
\hline L i nearity & .154 & 34,443 & 0,000 \\
\hline \multicolumn{5}{l}{ Source: SPSS Data 16.0 for windows }
\end{tabular}

Based on the table 5 can be seen in the ANOVA Table output. It can be seen that the significance value at linearity is 0,000 , then the significance is small than 0.05 $(0,000<0.05)$. Then it can be concluded that between social support variables and assertive behavior, there is a linear relationship, then the assumption of linearity is fulfilled.

Hypothesis testing is done using Pearson correlation analysis to determine whether there is a relationship between social support and assertive behavior. Based on the results of calculations using the SPSS program version 16.0 for windows, the following results are obtained:

Table 6 Hypothesis Test for the distribution of the Social Support Scale and Assertive Behavior Scale

\begin{tabular}{ccc}
\hline Variable & Pearson Correlation & Sig \\
\hline $\begin{array}{c}\text { Assertive social- } \\
\text { behavioral Support }\end{array}$ & .392 & 0,000 \\
\hline
\end{tabular}

Source: SPSS 16.0 for windows

The results of the analysis in the table 6 above shows that the Pearson correlation coefficient value of social support and assertive behavior in students majoring in Islamic Counseling Guidance Imam Bonjol Padang is 0.392, and Sig's coefficient is 0.000 . If a significance value of fewer than 0.05 means the hypothesis is accepted, if a value of greater than 0.05 means the hypothesis is rejected. $\mathrm{N}$ use-values the significance of social support with assertive behavior in students majoring in Counseling Islam Imam Bonjol Padang UIN is $0.000(0.000<0.05)$, which means the level of significance between two variables showed a relationship between social support $d$ ith assertive behavior in students majoring in Counseling Islam in UIN Imam Bonjol Padang. Based on the research conducted, the significant value obtained from social support and assertive behavior is $0,000 \quad(0,000$ $<0.05)$, which means that the significance level between the two variables shows that there is a relationship between social support and assertive behavior in students of Islamic Counseling Guidance Imam Bonjol Padang. The Pearson correlation (Product Momment) Coefficient obtained is 0.392 . This means a significant level between the two variables indicates a positive relationship, namely between social support and assertive behavior. While the value of $\mathrm{R}$ square shows the number of 0.154 , which means the contribution of social support for assertive behavior is $15.4 \%$.

\section{DISCUSSION}

The results of these studies lend some support to arguments that counseling interventions could be used to equip persons with interpersonal and social skills that could be used to access and use social support. Previous research has not clarified the interaction between social support and interpersonal behavior. Personal assertion skills apparently do moderate the effectiveness of several types of social support, according to 
the present findings. Assertion training has been found to be generalizable to a person's natural social environment and it is also considered to be more specific and efficacious than relationship-oriented approaches in helping clients acquire effective interpersonal skills. On the basis of the present results, we believe that assertion training programs could directly effect the quality and effectiveness of a client's social support systems. Clients would need to be taught those conditions in which assertion might be adaptive in interacting with others when stressedThe results of the second study replicate and extend the findings of the first study. The beneficial effects of social integration were moderated by the level of personal assertiveness under stressful conditions in the prediction of depressive behavior.

Many other factors influence the level of assertive behavior in individuals besides social support variables. Rathus and Nevid (in Nabila, Hardjono, \& Nugroho, 2012) suggest factors that influence assertive behavior, namely internal factors consisting of age, sex, self-esteem (self-esteem) and external factors including of parenting age, culture, and the environment ( social). This is in line with Pramudarwani research (2018), which found that the useful contribution of the social relations variable of peers to assertive behavior was $14.36 \%$. Furthermore, a study conducted by Anfajaya and Indrawati (2016) results shows that self-concept contributes effectively by $33.7 \%$ to assertive behavior. This indicates that there are indeed other factors that influence assertive behavior besides social support. The results of this study indicate the results of the social support category for students majoring in Islamic Counseling Guidance, of the 182 students studied, 65 students or $35.7 \%$ had low levels of social support, 117 students or $64.3 \%$ had high levels of social support. While in the categorization of assertive behavior, as many as 133 students or $73.1 \%$ have a low level of assertive behavior, and 49 students or $26.6 \%$ have a high level of assertive behavior.

Based on the results of the study, students majoring in Islamic Counseling Guidance have low assertive behavior. If students do not implement assertive behavior in their social life, it can lead to unhealthy support, unwilling to express feelings, often angry, and then will spend time and energy because they have said or done something that can cause others to realize their existence. Meanwhile, if the students have assertive behavior, then it will make them able to get along honestly and directly, be able to express their feelings, needs and ideas, be prepared to act in their interests initiatives I'vetiative to meet their needs, and be able to find satisfactory solutions when conflicting with others (Adam \& Lenz, 199). To behave assertively, someone needs another individual who can provide social support to him. Cohen and Wills define social support as the help and support that a person receives from his interactions with others. Social support arises from the perception that there are people who will help in the event of a situation or activity that is seen to cause problems, and the assistance is felt to increase positive feelings and lift self-esteem. Assertive behavior is not innate or not the nature of one's personality, but are patterns that are learned as a reaction to social situations in life there, therefore, essential to look at external factors that influence assertive behavior. Based on this research, students tend to have low assertive behavior. To improve assertive behavior, it can be done by conducting confident training, such as with group discussion roleplaying.

\section{CONCLUSION}

Based on the results of research in the discussion, it can be said that there is a relationship of social support with assertive behavior in students majoring in Islamic 
Counseling Guidance, UIN Imam Bonjol Padang. Even so the correlation is negative, where high social support (strong) actually gives birth to weak (low) assertive behavior. This means that although the social support received by students is good, it does not necessarily make a positive contribution to their assertive behavior. So there are still other factors that can explain the relationship between the two variables. For example; personalities possessed by lecturers, teaching methods that are run by lecturers who teach in class, learning atmosphere, material taught and so on. Then the closeness of the relationship between social support and assertive behavior of students is relatively low. This means that both variables contribute significantly less. Where social support is an absolute factor in the realization of assertive behavior among students.

\section{RECOMMENDATION}

Based on the findings of the study conducted in this study, the recommendations given include: (1) Educational institutions need to create a comfortable and pleasant learning atmosphere, so that the learning process provides comfort for students. (2) The lecturers, more motivating students to dare to argue or argue, so that two-way communication between lecturers and students provides support for the creation of assertive behavior from students. (3) Students, need to respect each other and assume that the differences of views between them are positive things between them, namely as evidence of the cognitive and innovative processes of thought that they have. Also means that differences of views do not have to mean conflict, but rather enrichment of thought between them. (4) To improve the closeness of the relationship between social support and assertive behavior students need other variables (intermediate variables). For example; age, sex and educational background (public school or religious school). So that this can be taken into consideration for other researchers to follow up on studies that have been done by researchers.

\section{REFERENCE}

Adams, L. a. (1994). Be Yourself. Jakarta: Gramedia.

Adam, L. \& Lenz, E. (1995). Jadilah diri anda sendiri: Be your best. Efektivitas pribadi dalam hidup dan hubungan anda. Jakarta: Gramedia Pustaka Utama

Anfajaya, M.A. \& Indarwati, E.S.(2016). The Relationship between Self-Concept and Assertive Behavior in Organizational Students of the Faculty of Law, Diponegoro University, Semarang. Semarang : UNDIP.

Eliusuk, A. G. (2014). The impact of assertiveness training on interpersonal problem solving perceived social support and assertiveness of university students. Bartin University. Journal of Education , 456-474.

Fransiska. (2007). Hubungan antara Perilaku Asertif dan Kecemasan Presentasi Proposal Penelitian Skripsi pada Mahasiswa. Skripsi tidak diterbitkan. Yogyakarta: Universitas Sanata Dharma

Hasanah, N. S. (2012). Improving Student Confidence Through Assertiveness Training. Brawijaya University. Jurnal Universitas Brawijaya, 10-20.

Hojjat, S. G. (2016). The effectiveness of group assertiveness training on happiness in rural adolescent females with. Journal Health Sciencces, 156-153.

Jan Sheinker, A. S. (1988). Metacognitive Approach to Social Skills Training. Maryland:Aspen. 
Lambertz, M. \&. (2016). You don't have to like me, but you have to respect me: the 1mpacts of assertiveness, cooperativeness, and group satisfaction in collaborative assignments. Business Professional Qarterly, 180-199.

Nabila, A. H. (2012). The Effect of Providing Assertiveness Training on the Tendency of Juvenile Delinquency in Class X Students of SMK Bhineka Karya Surakarta. Jurnal Psikologi, 20-30.

Pramudarwani. (2018). Relationship between Peer Social Relations with Assertive Behavior. . Surakarta: Universitas Muhammadiyah Surakarta.

Priyatno, D. (2014). SPSS 22 Practical Data Processing. Yogyakarta: Andi.

Smet, B. (1994). Psikologi Kesehatan . Jakarta : Gramedia .

Uzuntarla, Y. C. (2016). Analysis of universty students' assertiveness level. TAF Preventive Medcine Bulletin, 95-104. 